\title{
Social Class and Islamic Identity: Chinese Uyghur Students and Working Class in Turkey
}

\author{
By David Makofsky* \\ Bayram Unal \\ Maimaitijiang Abudugayitit
}

\begin{abstract}
Using a sample of Uyghurs in Turkey, we are testing the inclusion of social class, gender and Islamic customary practice on 'modernization theory'. 'Modernization theory', developed in the 1960's by applied social scientists from a Weberian-oriented tradition has had its own shortcoming: it proved to be too general to be useful. By specifying its application to the contemporary Islamic world, we hope to improve its utility. A questionnaire was developed concerning issues raised in the process of the modernization: ethnic identity, the maintenance of customary Muslim community practices, social class and gender differences. A sample is drawn from Uyghur students and professionals in Turkey in the spring of 2015, and then supplemented by visiting a Uyghur refugee camp in Turkey All the respondents were born in Xinjiang, in North West China and most of them were visiting exchange students from China or working-class Uyghur refugees as the situation in Xinjiang worsened after the 2009 uprising. The study compares the distinctive cultural-historical characteristics of Islamic modernization to that of Western modernization.
\end{abstract}

Keywords: Muslim China, Muslim Identity, Muslim 'modernization', refugees, social class, Uyghurs

\section{Uyghurs, 'Modernization' Theory, 'Islamic Liberalism'}

There is now widespread interest in an Islamic group in Chinese Central Asia, the Uyghurs (China Digital Times 11/2018). Although the situation in the Xinjiang province of China is increasingly difficult, this study was carried out three years ago in Turkey, and the situation was not so dangerous. Everyone who has been interviewed was born and raised in the Muslim and Turkic speaking area of Uyghur Independent Republic of Xinjiang, one of the northwest provinces of China.

The Uyghurs, together with their close linguistic neighbors, the Uzbeks, are among the most populous of the Turkic speaking Muslim people of Central Asia who live in the vast region of grasslands and mountains that stretch from the Mediterranean to the center of China, Xian. Numbering between 10 and 15 million in the home province and all over the country, the Uyghurs are one of the largest ethnic groups in China. Their nomadic ancestors migrated westward from the Eastern part of Central Asia to what is now contemporary Anatolia over the course

\footnotetext{
*Adjunct Professor, Indiana University Northwest, USA.

${ }^{\dagger}$ Associate Professor, Sociology, Nigde University, Turkey.

${ }^{\ddagger}$ Graduate Student, Ankara University, Turkey.
} 
of many centuries, but among those who remained in distinct oasis communities along the Silk Road are the Uyghur Turks. The Uyghur dialect is considered close to 'old Turkish'.

Uyghur civilization itself grew up among the central Asian oasis cities of 'The Silk Road': Aksu, Kashgar, Hoten, and Turfan. Their conversion to Islam was not completed until the Sixteenth century, although the great contribution to the development of Muslim culture was the project of Mahmud Kashgari, (Divan-i Lughat Turk) completed in 1072-1074. Previously, Nestorian Christianity and Buddhism had made significant inroads, although the earliest religions were those of shamanism and of Zoroasterism. After the establishment of the People's Republic of China (PRC) in 1949 and the incorporation of Xinjiang in the 1950's, the PRC made a substantial investment in the region. The province is rich in mineral resources. Xinjiang's economy by today's standards in China is relatively well off, although most Uyghurs are relatively poor by urban South East Chinese standards.

There is a large body of research chronicling the history of the Uyghur - Han (Chinese) relations, which echoes both cooperation and conflict continuing over many centuries and dating back to the construction of the Great Wall. The "conflict" literature documents everyday hostility (Bovington 2002) as well as popular protest on a regular basis (Gladney 1992, Bovington 2002, Millward 2009, Baranovitch 2003). Much of this discontent and mistreatment is available in the writings of the Uyghur scholar, Erkin Emet, who serves as a principle Uyghur voice on matters of ethnic relations in the Uyghur professional community. One of his works is introduced here (2015), but the English source for his work is in broadcasts for Radio Free Asia.

As with many their Muslim neighbors in the Central Asia and the Middle East, Uyghur society is undergoing a change comparable to that described in Europe by the labor historian E.J. Hobsbawm (1989, 1999). The "Dual Revolution" that led to the creation of Modern Europe was that of industrialization and political awakening that appeared in Europe in the 19th Century. Those revolutions spread out to the rest of the world through the processes of trade, war, and imperialism and played an important role in the world wars of the $20^{\text {th }}$ century. What makes frameworks such as those of labor historians important is that they are describing the cultural and psychological process of change, and this is an important issue in the theory of 'modernization'. Hobsbawm, for instance, understood 'revolution' not merely as a change in the state, or government, but a change in a value system, an attitude towards the work, religious behavior, and the family.

Contemporary social transformation in the world of Islam is parallel to these earlier developments - with a critical difference. The arrival of the modernizing revolution in the mid-20th century in the Islamic world (an area much extensive than the Middle East) came to cultures that have been colonized over the past hundred and fifty years. The Western and other powers that threatened Islamic culture were viewed as 'foreign' by the some of the local population, paralleling the relation between the Uyghurs and the 'new' Communist China as they had with the 'old' Qing Dynasty. The role of secularism, a key component to the value change 
in Western European experience, has a unique and perhaps more serious obstacle to face in the form of Islamic culture.

Four historical conditions link the Middle Eastern, North African and Uyghur Central Asian modernizing movements:

a. Unlike the Western experience, much of the world of Islam has been ruled by foreign powers - this is the modernization of the colonized either through direct occupation or through the more indirect neo-liberal economic model.

b. Popular protest in the Muslim world occurs in a political environment where there are very few features of what we in the West call 'civil society'. Civil institutions such as newspapers or legal associations independent of the state are relatively weak. Movements that might have a potential for new ideas have little access to the general public.

c. This process of change has come into conflict with customary practices in the Muslim community. Popular conceptions of 'Islamic practice' have been threatened, and that represents a challenge to people's identity as Muslims, and a genuine popular confusion over what happened to the 'world that has been lost'.

d. Although it would appear that secular nationalists represented authentic popular leaders in the post-colonization period after 1950, the tension between secular nationalism and Muslim faith and practice has proven to be far more important than was previously imagined.

In these terms the major focus of attention here is not on Uyghur-Han conflict; rather it is on the Uyghurs as a Muslim group and part of the process of 'Muslim modernization'. The social dynamics was formerly seen through the theoretical lens of the post-World War II world, represented by the 'modernization hypothesis'. This hypothesis incorporated large part of the nineteenth and twentieth century European experience and applied it throughout the world. Unrest, unhappiness, and the discontent of the poor - the cause of the problem and its solution were political and economic in nature. The introduction of the capitalist economy and its distinctive specialization of labor represented a new mode of production that unsettled the previous economic order. Political unrest grew out of the rise of a 'new classes' (organized workers, businessmen) demanding representation and the anticipation of democratic freedoms - see Hobsbawm's $(1989,1999,2004)$ writings on the European experience.

The modernization hypothesis incorporated a view of change in attitudes. Three types of 'personality types' or 'outlooks' were associated with these changes - 'traditional', 'transitional' and 'modern'. Postmodernist critics of this approach to 'modernism' claim that this approach to identity, typified by Daniel Lerner (1958) represents a relatively static and 'essentialist' approach to identity that is not consistent with the situation of Muslims (Gest 2015:1873). The attitudinal feature most associated with modernity was "empathy", that is, the capacity to see oneself in the other fellow's situation. (Lerner 1958: 49). Empathy, then, would lead the person to desire the lifestyles and values exercised in those far-away lands, and 
Western 'modernization'-ists are held to be secular equivalents of Christian missionaries.

The application of the 'modernization hypothesis' began with the study of Arab, and Turkish societies in the Mesopotamian area after World War One, but also involved the Muslim peoples of Central Asia as part of the revolutionary events in Russia and China. Political conflicts after World War One (July 1914November 1918) led to the establishment of modern Turkey and the creation of European-administered colonies in Iraq, Syria, Egypt and Lebanon. Similarly, after World War II (September 1939-August 1945) 'native' military leaders in Egypt Iraq and Syria led nationalist movements governed the state through modern secular organizations. In the Middle East the army, Muslim and secular, was at the center of this process. These movements resembled in some form the movements that laid the foundation for the Western European states of the $19^{\text {th }}$ century. The military nationalist regimes were and to a large extent have remained single party 'republics', authoritarian but committed to economic development and the extension of public education and welfare. In Central Asia the Muslim people were remote from the urban centers and viewed the new revolutionary governments with some skepticism.

\section{Empathy and Secularism: Muslim Liberalism}

An American sociologist with a Muslim background, Mansoor Moaddel, made the following observation distinguishing between Muslim experiences in various settings. Moaddel contrasted two types of Islam (1999: 108-109):

"From the nineteenth century on, Europeans and their westernized allies in the Islamic countries have predominantly condemned Islam for its mistreatment of women. The responses of the Islamic scholars have been diverse. In Islamic fundamentalism, there is an outright attack on the West for its cultural 'decadence' and sexual promiscuity. (Muslim) Women are instructed to cover their bodies from head to toe with the exception of the face."

"In contrast, a group of modernist Muslim theologians, notably in India and Egypt around the turn of the century (1900), advanced a modernist exegesis of the Quran, arriving at an Islamic feminist conception of gender relations. These scholars championed women's rights to education and involvement in social affairs, questioned the existing restrictions on women, criticized men's attitudes and behavior toward women and rejected polygamy."

Moaddel (1999: 111) argued that liberalism in Egypt and India was made possible by the decline of the old Islamic elite. "As a result, the requisite social resources and space for new culture production were provided, a pluralistic discursive field emerged, and the growth of Islamic modernist discourse was made possible".

Liberal Muslim thought cannot be understood as limited to the condition of women. It involves the rethinking and reformulation of an entire set of cultural values. Secularism and rationalization involve the reforming of institutions to train 
a professional class. Although Moaddel refers to Egypt and India, its impact can be felt throughout the world of Islam.

\section{Study Group, Methodology}

A sample of Uyghurs was used to investigate the identity formation through a psychological framework employed in the study of Muslims in Europe (Gest 2015). The framework uses a "postmodernist" approach to identity formation. The investigation reported here follows two years of research in the Uyghur home region of Xinjiang - see Makofsky, (2013, 2014). It is not possible to systematically sample Uyghurs in Xinjiang province in China, since the police make it difficult to talk to ordinary citizens.

Almost all of the Uyghur students in Turkey for that year that were associated with the Uyghur welfare associated were sampled, and so there was no systematic exclusion, and a questionnaire was administered. The questions dealt with attitudes towards secularism, national identity, and attitudes towards customary Muslim practice in their community, the Xinjiang Autonomous Province in China.

A comparison to the attitudes of working-class Uyghurs was desired, and to obtain that we approached those who headed a large Uyghur refugee camp near Kayseri in Anatolia. Some historical context should be given: The new China' had been established in 1949, but in the weeks around July 5, 2009, there was a Uyghur uprising in factories and eventually in Urumqi, the capitol of Xinjiang province (Millward, 2009). Disturbances have continued, and the situation has been termed a 'limited war' by the Mercator Research Center on China (Julienne, et al. 2015). All of those questioned were Chinese citizens now in Turkey. The situation has deteriorated to the point where it is reported that there are hundreds of thousands of Uyghurs held in "re-education camps" back in China (China Digital Times 11/2018).

One part of the sample is from the better educated children of Uyghur society, attending college and/or doing graduate or professional work. In general, their parents probably lacked these educational opportunities because it was not until this generation that modern higher education (high school, college, university) extended to Xinjiang. All in the sample are in touch with Uyghur support organizations in Turkey, and all are of the Muslim faith. This is a convenience sample and, there is no way to determine if these exchange students and longerterm residents were representative of the population of young Uyghur college students in China or any defined population. The Uyghur support organization helped distribute the questionnaire to students from China visiting Turkey and young Uyghur professionals living in Turkey. Most of the respondents were in their twenties. Nearly every Uyghur who was in touch with the organization in the spring of 2015 was asked to fill out the questionnaire; some were interviewed in person afterwards.

The other group in the sample were Uyghur refugees in Kayseri, a city in central Turkey that houses a large refugee camp run by the Uyghur support organization. Immediately after the revolt of 2009 this camp was established. 
Some have left the camp, more have come, and now there are more than 2000 Uyghurs in the Kayseri camp. Originally most of those in Kayseri were Uyghur factory and construction workers living in migrant worker camps and tents in Urumqi.

Data gathered in Kayseri among working class refugees was not easy to obtain. Our Uyghur assistant associated with Professor Erkin Emet helped gather more than 50 people after a Friday (Cuma) group prayer at the mosque. The questionnaires were distributed, and the questions were read one by one. But when the questionnaires were collected, it was found that many of the refugee respondents did not fill them out correctly. For example, many of them filled in all four answers for a single question. They knew which answer they wanted to choose, but they didn't understand how to mark the answer. Some people left some questions blank. So, the interviewer stayed there for a few hours, and let respondents make corrections. There are obvious limitations to this approach, but the fact is that attitudes of the working class are central to the process we are describing.

\section{Who Is Being Surveyed? Demographic Characteristics of the Three Groups}

Uyghur Kayseri (refugee) male - there were 52. The sole female in the group, a teen aged girl, was excluded since one finding of this investigation is that significant gender differences exist.

Uyghur male students - there were 54 gathered in Ankara and Istanbul in the spring of 2015 and more were gathered in 2016.

Uyghur female students there are 30 gathered in Ankara and Istanbul in the spring of 2015 and more were gathered in 2016.

Age

Kayseri (refugee) males: The median age is 29 years. The range includes 5 in their young teens and 2 in their 50's.

Uyghur student males: Of the 54 gathered in 2015 the youngest was a 16year-old, the median age was 25 and there is one fellow in his 40's. Most are in their 20's.

Uyghur student females: Of the 30 gathered in 2015 there were two teenagers, and one woman over 30 . The median age is 24 . This is a very homogeneous group.

\section{Questions Raised by the Data}

\section{Attitudes towards' Islam' - Muslim Customary Practice - Where are the Secularists?}

What is 'Islam' - the definition being used here is the adherence to customary 
Islamic practice relative to their community.

The first set of questions sets forth the first paradox - every respondent appears to follow Islamic customary practice

Table 1. Question: 15. I Will Only Eat Hallal Food (\% in row)

\begin{tabular}{|l|c|c|c|c|}
\hline Category & Agree & $\begin{array}{c}\text { Neither agree } \\
\text { nor disagree }\end{array}$ & Disagree & Total \\
\hline Refugee males & $51(98.08)$ & 0 & $1(1.92)$ & 52 \\
\hline Student males & $54(100)$ & 0 & 0 & 54 \\
\hline $\begin{array}{l}\text { Student } \\
\text { females }\end{array}$ & $28(93.33)$ & $1(3.33)$ & $1(3.33)$ & 30 \\
\hline
\end{tabular}

Table 2. Question 5. I Will Only Marry a Muslim (\% in row)

\begin{tabular}{|l|c|c|c|c|}
\hline Category & Agree & $\begin{array}{c}\text { Neither agree } \\
\text { nor disagree }\end{array}$ & Disagree & Total \\
\hline Refugee males & $51(98.08)$ & 0 & $1(1.92)$ & 52 \\
\hline Student males & $44(83.02)$ & $7(13.21)$ & $2(3.77)$ & 53 \\
\hline $\begin{array}{l}\text { Student } \\
\text { females }\end{array}$ & $28(93.33)$ & $1(3.33)$ & $1(3.33)$ & 30 \\
\hline
\end{tabular}

Table 3. Question17. I Do Not Drink Beer or Alcoholic Beverages (\% in row)

\begin{tabular}{|l|c|c|c|c|}
\hline Category & Agree & $\begin{array}{c}\text { Neither agree } \\
\text { nor disagree }\end{array}$ & Disagree & Total \\
\hline Refugee males & $51(98.08)$ & 0 & $1(1.92)$ & 52 \\
\hline Student males & $52(96.30)$ & $2(3.70)$ & 0 & 54 \\
\hline $\begin{array}{l}\text { Student } \\
\text { females }\end{array}$ & $28(93.33)$ & $1(3.33)$ & $1(3.33)$ & 30 \\
\hline
\end{tabular}

Table 4. Question 22. I Always Fast During Ramadan (Razi) (\% in row)

\begin{tabular}{|l|c|c|c|c|}
\hline Category & Agree & $\begin{array}{c}\text { Neither agree } \\
\text { nor disagree }\end{array}$ & Disagree & Total \\
\hline Refugee males & $50(96.15)$ & 0 & $2(3.85)$ & 52 \\
\hline Student males & $47(87.04)$ & $4(7.41)$ & $3(5.56)$ & 54 \\
\hline $\begin{array}{l}\text { Student } \\
\text { females }\end{array}$ & $27(93.1)$ & $1(3.45)$ & $1(3.45)$ & 29 \\
\hline
\end{tabular}

$\underline{\text { Statistical Significance }}$

In Tables 1-4, the agreement of respondents in this community towards issues central to Islamic practice is in only one case less than $90 \%$. This, in itself, is a remarkable finding.

This is not a group of Wahhabi imams from Saudi Arabia or orthodox Hassidic Jews in Rockland County, New York. The Kayseri refugees aside, this is a group of Chinese college and graduate students in their teens and twenties getting degrees in Ankara and Istanbul. All of them were raised in a secular culture in a secular country, the Peoples Republic of China. Although some may have been brought up in the small towns of Xinjiang, most of them have spent at least one year in Beijing, Shanghai, Ankara, or Istanbul, and have been exposed to bars, 
strip clubs, pornography, and U.S. influenced media, which is exhibited in shopping malls worldwide. The young men watch action movies, such as the Fast and the Furious; the young women have favorite movies such as The Devil Wears Prada or Titanic.

To make things even more curious, it should be pointed out that, despite what the respondents appear to be saying, these Muslim norms are not regularly practiced. Uyghur boys boast about going out with Chinese or Turkish girls (re: I will only marry a Muslim). In Kashgar some Uyghur restaurants open for breakfast during Ramadan (re: I always fast during Razi). Often, respondents, especially male, will say that they once drank, but now they do not. Especially outside of Xinjiang women may not wear head covering at all.

This highlights the distinctive character of the expressed attitude towards Islam. The "postmodern" psychological approach highlights the fluidity of identity formation (Gest 2015:1874). Rather than fitting into categories of "more secularist", which would be classified as 'transitional' in the approach termed "modernism" the real issue here is ethnic identity. Acknowledging Islamic practice is what makes the respondents "Uyghur"; otherwise, they are simply "Chinese". Even if they do not follow Islamic codes, they feel they must say that they do. It can be conjectured that these responses have more to do with Muslim identity rather than a description of individual practice. As we will see, such responses are given by Uyghurs in Turkey, by Arabs in Europe, and even by Muslim youth in their homelands. Responses such as these cannot be taken at face value since Islamic customary practice is not followed all the time, and yet violation of normative values may not constitute hypocrisy.

Among working class Muslim youth in Europe, Julian Gest (2015: 5) observes: "identity formation is a process. It is therefore important to use investigative methods that examine individuals' deliberative considerations as they make everyday choices in real time. In listening individuals' descriptions of their deliberations and choices regarding identity, it is possible to fathom how they understood the relationships among their different identifications and how they consciously and unconsciously attempted to transform or redefine these relationships in order to create a more coherent identity."

That coherent identity, in a changing world, is called "Islam". The form taken by that identity is the adherence to Islamic customary practice, and if that is the case there is only limited room for secularism.

Just as Questions I-IV are 'easy to answer', because the respondents certainly know the 'correct answer', other questions show less unified patterns.

Attitudes towards Women and towards Islamic Liberalism

Table 5. Question 4. Women Should Only Dress In An Islamic Way (\% in row)

\begin{tabular}{|l|c|c|c|c|}
\hline Category & Agree & $\begin{array}{c}\text { Neither agree } \\
\text { nor disagree }\end{array}$ & Disagree & Total \\
\hline Refugee males & $50(98.04)$ & $1(1.96)$ & 0 & 51 \\
\hline Student males & $41(77.36)$ & $8(15.09)$ & $4(7.55)$ & 53 \\
\hline $\begin{array}{l}\text { Student } \\
\text { females }\end{array}$ & $18(62.07)$ & $9(31.03)$ & $2(6.09)$ & 29 \\
\hline
\end{tabular}




\section{$\underline{\text { Statistical Significance }}$}

Question 4 prob (refugee males agree) $<=$ prob (student females agree) $<=$. 001.

Question 4 prob (student males agree) $<=$ prob (student females agree) $<=$. 01 .

There is a statistically significant difference between refugee Uyghur men and student Uyghur women representing the poles of Islamic fundamentalism / conservatism and Islamic liberalism There is also a statistically significant difference between student Uyghur men and student Uyghur women. Women are significantly more liberal with regards to customary dress practice.

When female respondents are questioned about this question, some saw it in a distinctive way. One young woman responded: "The Chinese do not allow us to wear headscarves in school." The Chinese government had given a great deal of publicity to the fact that the French do not allow headscarves for girls. Another female respondent had heard that French law limiting the use of Muslim head covering and asked what all of that had to do with Uyghurs. This is the issue, the sentiment expressed that to oppose Islamic dress for women is to betray the Uyghur cause. For these women, instead of the choice being framed as Islam against secularism, it was framed in national/ethnic terms as Chinese authorities imposing a choice on Muslim schoolgirls.

Table 6. Question 20. The Proper Place for Women is in the Home, with the Family (\% in row)

\begin{tabular}{|l|c|c|c|c|}
\hline Category & Agree & $\begin{array}{c}\text { Neither agree } \\
\text { nor disagree }\end{array}$ & Disagree & Total \\
\hline Refugee males & $46(90.2)$ & $4(7.84)$ & $1(1.96)$ & 51 \\
\hline Student males & $34(62.96)$ & $10(18.52)$ & $10(18.52)$ & 54 \\
\hline $\begin{array}{l}\text { Student } \\
\text { females }\end{array}$ & $12(40.0)$ & $8(26.67)$ & $10(33.33)$ & 30 \\
\hline
\end{tabular}

\section{$\underline{\text { Statistical Significance }}$}

Question 20 prob (refugee males agree) <= prob (student females agree) $<=001$.

Question 20 prob (student males agree) $<=$ prob (student females agree) $<=01$.

Refugee Uyghur males represent the most fundamentalist / conservative group in Islamic terms, Uyghur student women most liberal group in Islamic terms.

Student Uyghur males are more conservative in Islamic terms than Uyghur student females.

Lipset (1981: 92) surmised that two ideological elements prevailed "in the poorer strata everywhere" 
"The first element was a complex of attitudes ... referred to as economic liberalism i.e., the opinion that income, status, and power should be redistributed more equally in society, that government policies to establish this redistribution were desirable, that the government should introduce a graduated tax system, and that trade unions should become more powerful. The second element was another complex of attitudes that could be labeled non-economic conservatism, including the opinion that civil liberties ought to be restricted in general and for deviant groups in particular, that government policies should be anti-internationalist and pro-nationalist, and that the government should conduct a restrictive immigration policy."

Based on the historic Western experience, it is generally believed that the section of the population with lower income and less education possess the authoritarian attitudes that might attract them to fundamentalism. In the late 1950's Lipset published a well-known article Democracy and Working-Class Authoritarianism. His central thesis is that the working class (or the poor, the farmers, etc.), more than other social classes, is predisposed to authoritarian and anti-democratic attitudes. Although there has been much criticism of this thesis, it is often held that education and not social class seems to be the most important factor in determining authoritarianism (Dekker and Ester 1987).

The definition of Muslim liberalism deals with the relation of women to customary practice in Table 5 and 6 , Customary practices in the Muslim communities in China and in Turkey affect women's dress and social behavior.

Certain facts stand out from the responses to 'women dressing in an Islamic way'.

a. Islamic conservative/fundamentalist attitudes are related to agreement to the very judgmental questions 4 and 20, and there is a consistent pattern of conservative/fundamentalist -to-liberal beginning with refugee males followed by student males, with the most liberal being student females.

b. Within the student group there is a statistically significant difference between males and females concerning conservative/fundamentalism and liberalism. Uyghur young men seem to feel much more strongly about the necessity of Islamic dress for women, that is, they are more conservative towards Islam.

These women are a critical part of the generation of Muslim community 'modernization'. That is, they are in their twenties, they are too old to be told what to do and what to think. In today's Xinjiang, today's China, the generation of women being interviewed is older than the young adolescents married out of primary and middle school only a few decades ago. There are anecdotes from interviews to suggest girls remain in school to avoid 'early teen' arranged marriages, and therefore marry in their twenties. The older the girl, the more the evolved customary practice of arranged marriage works against young men. In Xinjiang, arranged marriage also include a 'bride price', and poorer Uyghur boys 
are at a definite disadvantage; an older girl may believe she has more options than accepting the male of her parents' choice. A young man may have to remain unmarried if his family has no money, and the younger and more attractive women are all married away.

Young men may be reluctant to marry a woman who may be perceived as being of higher status than they are. Some of these young men who were opposing arranged marriage may be boys unable to meet a good bride price and are seeing all their attractive female acquaintances married.

The right to work in outside-the-home employment, freedom of dress, the rights of the individual vs. parental control, the right to determine their own future are values that are pervasive, but not necessarily observed, in the West. These values are challenged by customary practice in the Muslim community in Xinjiang.

The few young men that discussed this framed it in a different manner. Young women should dress in an Islamic way - it was not simply a matter of the Chinese, but a matter of Islam. In any case, young men appear to be more in agreement that young women should dress in conformity with what they believe is Muslim practice. The paradox of all this is that in women's fashion in urban areas of Xinjiang such as Urumqi, which is North East Xinjiang and very Chinese, there is an intermingling of Islamic and Western ('Chinese') dress in almost all the public areas, such as the bazaar, the street, and in fast food restaurants. It is common to see women walking together, one in a Uyghur hijab and the other in what we might call 'Western/Chinese' clothes - although almost no Muslim woman wears form-fitting clothes.

Whether Muslim men are in China or in Europe, researchers find that men want to explore the "other" (Gest 2015:1876). Perhaps this is a special challenge, because the men want their wives to follow a "strict Islamic way". This may conform to the followers of postmodernist identity theory, that the Muslim men want the best of both the "traditional" and the "modern" types - a modern woman and an Islamic wife. Is this an example of a transition personality in identity, or is this an example of the fluidity of personality in the modern Muslim male?

Question 20, concerning employment outside the home raises many serious issues. Upon questioning, a few Uyghur female respondents simply did not want to work and hoped to find a suitable mate to support them. More important, once respondents are interviewed, it was found that questions of female employment are closely tied to two related questions - Do you want to live in Xinjiang? Do you want to live close to your parents? Obviously if women move to Beijing or Shanghai, they are more likely to find professional employment, live much further from community control, and much less likely to be subject to customary practice.

The problem of questioning this sample is that the response of young Uyghur college women is that they want and expect to find work commensurate with their education. In Xinjiang, for educated women urban employment may include teaching in college or grade school, office work, or translation work (Chinese to Uyghur, or reverse) for government agencies.

If a young woman prefers to live close to parents or in-laws, an affirmative answer means that their employment opportunities are very limited. This is 
especially true outside Urumqi, the provincial center of the government and the site of two major universities, the Art Institute, etc. Thus, one frequent response of educated Uyghur young women is that they want to live in Urumqi, and not in their hometown.

Working class employment for young men and women may include factory work. Based on conversations, it seemed clear to me that educated young women do not want to find factory employment. In China, it is an achievement to graduate from high school, although many do. In the past, especially for Uyghurs, high school graduation was rare. Wives of artisans and shopkeepers may work at home in needlecrafts, or in small shops, which also employ family members.

Let's try to understand what the male respondents may be driving at:

The questionnaires and interviews occurred during a national election in Turkey, and one young Uyghur male, referring to the question of female employment, made reference to what was considered to be a major event in the campaign. The popular Turkish 'Islamic' politician Recep Tayyip Erdogan made a statement to the effect that he had grown up with the Koran and lived with the Koran. 'This is an important thing to understand,' the young man explained. "Islamic teaching tells us that no man should see even the eyes of a faithful Muslim wife. At the least when a Muslim woman works, she does not work away from the eyes of her husband."

This narrative goes a long way to explain what some conservative Islamic oriented men might take to be the meaning of the question. Uyghur homes in suburban and rural Xinjiang are centers of economic activity. Uyghur residences have ample space for small domestic animals such as sheep, goats and chickens. Livestock is raised and traded and sold for a profit or may be slaughtered and sold for barbeque meat at a bazaar or on the street. At the bazaar a customer can find home produced goods, wrapped candy, handmade doppas (Uyghur caps).

Some young men are not saying that women should not work, rather, women should not GO TO work, they should work in the home and have the husband sell the product at the market. At times women sit in the market on blankets, not in regular stalls, and one day a week at the market may be exempted for this general rule of Islamic practice. In an interview with a wood products craftsman, his wife stayed at home and painted the products. Any citizen of China can attend Chinese language elementary, secondary, and university level schools, but in Xinjiang province there are regular schools up to the college level offering instruction in Uyghur.

To say, however, that women should not work away from the supervision of a husband or family member means that modern forms of employment are not available to women. This may limit opportunities in office or white-collar employment involving clerical-sales tasks and may limit professional employment in teaching or government work. For poorer families, this would limit female factory work, although this may not be practical. 
National Tradition versus Islam

Uyghur and Muslim, Uyghur or Muslim?

Table 7. Question1. Nowruz is not Muslim, so it cannot be celebrated by Uyghurs (\% in row)

\begin{tabular}{|l|c|c|c|c|}
\hline Category & Agree & $\begin{array}{c}\text { Neither agree } \\
\text { nor disagree }\end{array}$ & Disagree & Total \\
\hline Refugee males & $26(52.0)$ & $4(8.0)$ & $20(40.0)$ & 50 \\
\hline Student males & $20(37.04)$ & $9(16.67)$ & $25(46.3)$ & 54 \\
\hline $\begin{array}{l}\text { Student } \\
\text { females }\end{array}$ & $12(40.0)$ & $8(26.67)$ & $10(33.33)$ & 30 \\
\hline
\end{tabular}

\section{$\underline{\text { Statistical Significance }}$}

Question 1 prob (refugee males agree) $<=$ prob (student females agree) $<=.05$.

Question 1 prob (refugee males agree) $<=$ prob (student males agree) $<=.05$.

The refugee Uyghur Males are significantly are significantly more likely than the students to be 'Islamically conservative' - to support a more 'Islamic' rather than 'nationalist' and 'non-Islamic' interpretation of Uyghur history.

It may appear that Uyghur respondents very much wanted to create an identity that unifies Muslim customary practice and idealized vision of the Uyghur past. To make this an image of contemporary Uyghur identity is admirable, yet when young Uyghurs get down to specifics, this unity runs into a great deal of difficulty.

Among the festival days celebrated by the Uyghurs, Nowruz is different from the others; it is not an Islamic holiday. Nowruz is the ancient holiday of Central Asia, traditionally associated with Zoroaster, the famous holy man of Central Asia, who represents a pre-monotheistic philosophy of science and natural religion. For the large number of Central Asian people that follow this tradition of the zodiac, the year begins with the New Day when the Sun leaves the sign of Pisces and enters the sign of Aries, during the Vernal Equinox. This is all pre-Islamic.

The Uyghur ancestors were part of the people who adopted Shamanism and early Central Asian religions, and then followed Nestorian Christianity and Buddhism before the arrival of Islam in the Eighth century. The ties to pre-Islamic faith are rooted in popular culture. This is one of the cases where classifications such as "traditional" and "modern" follow conventional lines of identity formation, since if we maintain that rigid identification with Islam is "traditional" then the working class is a somewhat more traditional than the more educated students. Despite this, a sizable proportion of the refugees defend the folk holiday from a non-Islamic tradition. 
National Traditions vs. Islam

Figure 1. Ghazi Ahmet, Meshrep - Title and Artist not identified in the Questionnaire

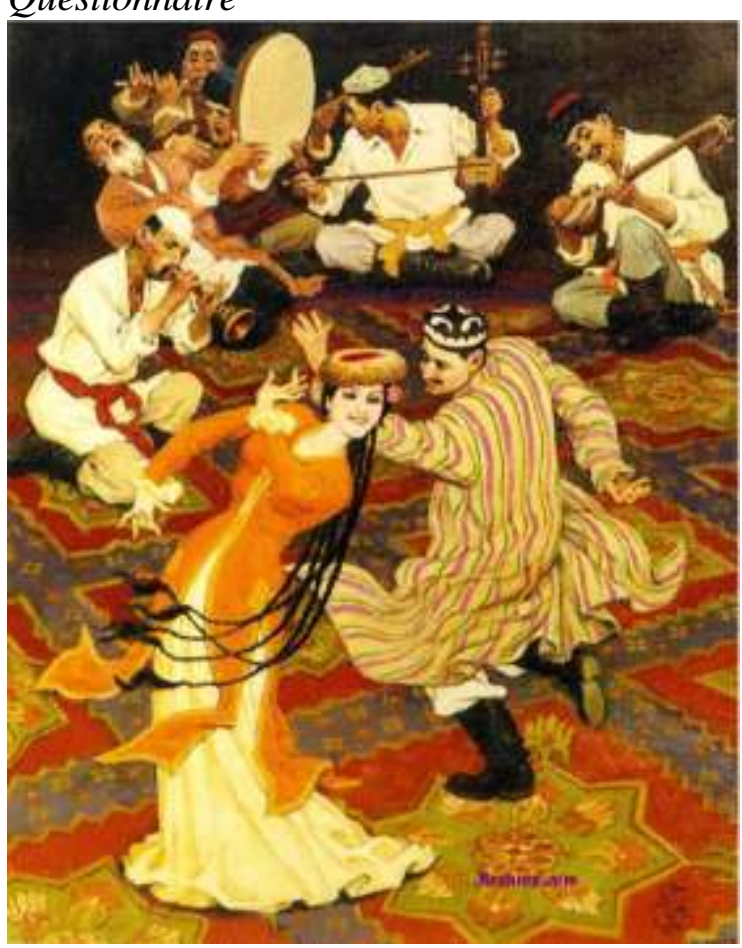

Source: https://bit.ly/2zFrHHh.

Table 8. Question 29. This (Figure 1) is not Muslim - It Is Not a Proper Uyghur Painting (\% in row)

\begin{tabular}{|l|c|c|c|c|}
\hline Category & Agree & $\begin{array}{c}\text { Neither agree } \\
\text { nor disagree }\end{array}$ & Disagree & Total \\
\hline Refugee males & $22(43.14)$ & $5(9.80)$ & $24(47.06)$ & 51 \\
\hline Student males & $16(29.63)$ & $14(25.93)$ & $24(44.44)$ & 54 \\
\hline $\begin{array}{l}\text { Student } \\
\text { females }\end{array}$ & $6(20.69)$ & $7(24.14)$ & $16(55.17)$ & 29 \\
\hline
\end{tabular}

\section{$\underline{\text { Statistical Significance }}$}

Question 29 prob (refugee males agree) $<=$ prob (student females agree) $<=001$.

Question 29 prob (student males agree) <= prob (student females agree) $<=01$.

There are statistically significant differences between student females and refugee marks and to a lesser extent between student females and student males. In both cases women are more 'Islamically liberal', and the students as a whole are more "Islamically liberal" than the male refugees. 
Table 9. Question 30 I would be happy to have this painting (Figure 1) in my home (\% in row)

\begin{tabular}{|l|c|c|c|c|}
\hline Category & Agree & $\begin{array}{c}\text { Neither agree } \\
\text { nor disagree }\end{array}$ & Disagree & Total \\
\hline Refugee males & $10(19.23)$ & $7(13.46)$ & $35(67.31)$ & 52 \\
\hline Student males & $22(40.74)$ & $14(25.93)$ & $18(33.33)$ & 54 \\
\hline $\begin{array}{l}\text { Student } \\
\text { females }\end{array}$ & $11(37.93)$ & $13(44.83)$ & $5(17.24)$ & 29 \\
\hline
\end{tabular}

\section{$\underline{\text { Statistical Significance }}$}

Question 30 prob (refugee males agree) $>=$ prob (student females agree) $<=.05$. Question 30 prob (refugee males agree) $>=$ prob (student males agree) $<=.05$

The refugee Uyghur Males are significantly are significantly more likely than the students to be 'Islamically conservative' - to support a more fundamentalist interpretation of the national history

What happens when Uyghur culture is inconsistent with Islam? This is asked in a question concerning Nowruz, a holiday, and in a question about a painting of a Uyghur celebration, Ghazi Ahmet's Meshrep (party) (see Figure 1, Table 8, 9). The problem with Figure I is the woman in the center of the painting. From her clothes, and from the dress and instruments of the men, this is clearly a Uyghur painting

In Figure 1 we see the work of a Uyghur modernist painter, Ghazi Ahmet. From a Uyghur tradition where the human figure, and especially the female body, is not shown in a painting, Uyghur modernist works are provocative. This painting has caused controversy since it was created. A Meshrep is a traditional party. This painting is well known internationally and was exhibited in Europe, but it still evokes criticism from the Uyghur respondents who see it as 'not Muslim'.

As in the previous discussion of identity, there is a great deal of tension in reconciling conservative Muslim values when these are in direct conflict with secular national identity. The painting is clearly not Muslim but was painted by a Uyghur and depicts a Uyghur celebration. As one student said, "Anyone who does not respect this painting does not know anything about our (Uyghur) history."

\section{Uyghur Attitudes on Islam Compared to other Studies of Muslim 'Attitudes'}

The object of this study is to consider how modernization theory, developed from the European experience, can be appreciated with the examination of the Muslim experience. Consider the questions that the interviews raised:

Uyghur Attitudes towards 'Islam' - Muslim customary practice -Where are the Secularists?

What does it mean to say, "I follow the basic tenets of Islam and customary practice"? Respondents often admit that some of these customs are not followed, 
but that is not the point. As one of Julian Gest's (2015) respondents said: "Islam simplifies. It's all about unification ... I am a Muslim. Not a Barelwi, Tablighi Jamaat, Salafi, Hanafi or whatever. I'm a Muslim. I'm not British or Bengali. I'm Muslim."

In the Western European experience, the modernizing states were the ruling powers and the same situation exists in China despite the ideology of the Chinese revolution. The 'third world' Muslims in both settings do not find they are participating in the world of events as a 'full citizen', whose models are available through decades of films and television. By this Twenty First century, many of those involved personally know or certainly have heard of those who find jobs either in major cities in their own country or in other countries. In that senses, all are refugees, a stranger in a new world deciding how much to accept of Islam and Islamic customary practice.

So Asef Bayat comments on the Arab Spring of 2011 (page 590):

"After having to make do with failing secular regimes and having turned to popular Islamic parties ... Islamist politics was such an unrivalled trend prior to the uprisings that, for many observers and policy makers, any real challenge to the despotic regimes would unleash Islamist revolutions in the region. Contrary to expectations, this was not the case. Surprisingly, the Arab revolts espoused the kind of aura, idioms, culture and constituencies that radically distinguished them from the earlier Islamist movements."

Again, Bayat: "Just as all do not follow the customary practice, it may even be a characteristic of our times that customary practice has more salience in the lives of Muslims. Many protestors appeared to deploy religious rituals (such as praying in streets and squares), utilizing religious times (Fridays) and places (like mosques); but these religious rituals are all part of the regular doings of all pious Arabs who perform them in everyday life, rather than carrying them out to Islamize the uprisings."

Secularism is a process as well as a philosophy. That is, secular elites may control education, but these same elites may not be secular humanists. Isaac Newton, one of the principal actors in the secularization of scientific investigation in England, was a devout Christian. It may also be said that secular humanism offers very little for the masses. It does not structure the time, the day, the place, and the holidays for those who wish a comprehensive faith, and Islam does exactly that.

From the writings on the of another investigator of contemporary Muslim identity, Juan Cole (2015: 275), the major parties of the states involved in the Arab Spring, Egypt, Tunisia, Libya, Syria began by offering freedom and an increased standard of living to the masses. Over the course of time the leadership in these states had become 'Republican Monarchs', leading corrupt administrations with weak legitimacy.

"Secularism", for a young Muslim often means a betrayal of ethnicity, not simply a refusal to respect religious practice. Depending on his/her relation to the dominant culture, the Muslim may be risking physical health or life career by their 
behavior. Rather than "fitting in" to an identity construct, the adjustment is constantly being negotiated. This is the major problem with "modernizing" theory as originally formulated. The researcher wants to classify while the individual actually "negotiates". In the sense of identity as negotiation, women are much better served by "liberalism", they obtain much more freedom, especially with the abandonment of teen aged arrange marriages.

\section{Uyghur Attitudes towards Women and Islamic Liberalism, they obtain more Freedom of Action}

Just as those who created 'modernization theory failed to appreciate the impact of the colonial experience and the weaknesses of secular leadership over time, similarly the resilience and deep-rootedness of the patriarchal culture was not appreciated. Seven decades after the victories of secular regimes in the Muslim world finds women's participation in the workforce restricted, and parentally arranged marriages taking place while girls were in their young teens (although this has changed a great deal).

Again, Gest (2015: 185): makes the following observation "Social discourse about Muslims and Islam has been dominated by the promulgation of images portraying an irreconcilably foreign and illiberal group of young men and suppressed women to characterize a religion that is arguably more ethno culturally heterogeneous than any other. Such imagery has been, to a large extent, the product of reactionary efforts to construct and root simplistic essentialisms amid and also because of - the perception that Islam is competing with national identities." Yet as we saw in the surveys, among the Uyghurs, that the attitudes and behavior of women represent the unspoken face of challenge to Muslim conservatism - everyone seems to be concerned about what Muslim women wear, whether or not the continue with their education, who they date, who they marry, when they marry - the behavior of males is of no interest at all.

In Turkey, there is a burgeoning feminist movement and there is a body of self-reflecting feminist thought (Alemdaroglu 2015:59): "I have many men around me. I know they are interested in me, but I do not think of any of them seriously. Having a serious relationship seems nonsense. Why should dating somebody bring more restrictions? Why would I want that? I see a lot of contradictions. Men want to keep the traditional values alive. I challenge their expectations in many ways. I have started to think that to tolerate that mentality is very meaningless... As women become more educated and get high-status jobs, they refuse to be as submissive as their mothers. However, it takes time for men to realize that women are no longer village girls or high- school graduates."

Although the responses of women in the survey were significantly more liberal than that of the man the Arab urban societies, as Cole points out (2015: 271) too often, in corrupt Arab societies such as Egypt and Tunisia, issues such as feminism are the hallmark of the wives of the political elites -it is often necessary to uncouple feminism from Suzanne Mubarak or Leila Ben Ali.

Among European migrants we find that perceptions of discrimination were found to also contribute to a strengthened Muslim identity between European-born 
Turkish and Moroccan immigrants in urban areas of Belgium, Sweden, and the Netherlands (Just 2014: 128), although there is some evidence that this relationship weakens when childhood religious socialization is taken into account. Similarly, interviews with Muslim women in France showed that the majority of second-generation Muslim women chose to wear the veil as a reaction to the debates over headscarves in public spaces (Just 2014: 130).

\section{National Tradition versus Islam}

\section{Uyghur and Muslim, Uyghur or Muslim?}

If there is one area of debate in which the Muslim world faces its greatest challenge, it is in the conflict between Islam and national (secular) traditions. Are we seeing another stage of change after the "secular monarchies" and populist Islam? Is this world now affected by what Asef Bayat terms both a 'post-Islamist orientation' and a 'non-movement' movement (2013: 589)?

"Since the 1980s, activism had remained limited to traditional party politics, a tired method that lost much of its efficacy and appeal by the mid-2000s. Radical Islamists had resorted to Leninist-type underground organizations; student activism was forced to remain on campus; laborers, going beyond conventional organizations, launched wild-cat strikes; middle-class professionals resorted to NGO work; and all embraced street politics when permitted, for instance during demonstrations in support of the Palestinian cause. But the vast constituencies of the urban poor, women, youth and others resorted to "non-movements" — the non-deliberate and dispersed butcontentious practices of individuals and families to enhance their life chances. The urban poor made sure to secure shelter, consolidate their communities, and earn a living by devising work in the vast subsistent and street economy. Muslim women strove to assert their presence in public, go to college, and ensure justice in courts. And youths took every opportunity to affirm their autonomy, challenge social control and plan for their future, even though many remained atomized and dreamed of migrating to the West."

Certainly, Juan Cole seems to agree with this evolutionary hypothesis. In his work on "The New Arabs", Cole observes a transition from the traditional monarchies, to the republican monarchies - of Syria, Egypt, Iraq, Tunisia, Libya. This authoritarian cycle has been disrupted by the rise of a group he calls "the new left", an alliance between a young new force of educated urbanites and a working class that sees no point of a blind allegiance to "old leadership". Cole's framework is not as amorphous as that of Bayat, since he sees in the Egyptian (failed) revolution and the Tunisian (successful) revolution the basis for a new socialpolitical constituency in Muslim politics.

What is interesting about all of this is the unseen shifting of "non-ideological" support of the "street", first behind the secular regimes, then behind the Islamic parties, then behind the Islamic-secularist response.

Very similar attitudes can be seen in the Uyghur sample. On matters dealing with secular affairs and national ethnic identity, the educated group of men and 
women are more uniformly secular and question the "conservative Islamic" stance. The working class on these issues is more divided, and the entire discussion drifts in a more liberal and secular direction.

\section{The Hesitant Liberals}

Uyghur Muslim identity is hardly fixed or adequately described by references to what is 'essential' to Islamic identity. As in Europe and the Middle East, some part of Uyghur identity is formed by the negative element in what has become what many believe to be their colonial experience under the Chinese. In the Middle East, continual military intervention of European/US imperial powers and now of Saudi/Gulf State or Iranian forces play a large part in creating indifference towards 'Western' values. For the Uyghurs, this negativity is not a fixed trait of identity, since there are many instances of extensive Uyghur cooperation with the Chinese government. A report on the affirmative action program in the PRC (Makofsky, 2014) documents the extensive efforts in the field of education and employment that have become an important component that has shaped Uyghur intellectual and professional life.

For the Muslims themselves, looking at the evidence, two generalities can be made concerning Islamic identity. The first is that there is a tacit alliance between Muslim males, educated or not, to retain separate and unequal spheres of influence between men and women, and to insist that this is 'natural' and that this is 'what women want'. A systematic look at the many studies -there is a Turkish feminist movement and I have cited two examples (Alemdaroğlu 2015, Just 2014) - would convince anyone that the application of Muslim customary tradition is neither 'natural' nor is it 'what women want' since it is hardly clear exactly what it is that Muslim women want. The 'post modernist approach to identity' itself denies that any set of choices are more 'natural' than any other.

The second major issue that faces Muslims is the conflict between secular and national tradition and that of the tenets of Islam. Despite the successes of 'Islamic populism' with the Muslim Brotherhood and Erdogan's AKP party in Turkey, it is a big step to imagine educated support for Islamic conservatism/ fundamentalism. In terms of Islamic conservatism, the educated classes, men and women, have too much respect for the historic gains of ethnic secularism and nationalism, and the working class itself is quite divided on these matters. As Gest points out in his study, there is a strong desire on the part of many Muslims to see nationalism and Islam proceed together. In the Middle East, this occurred both among the Shi'a supporting the Iranian Revolution and the Sunni supporting the Muslim Brotherhood.

In the refugee sample and the student sample, we see communities of young Uyghurs who are inclined towards the fulfilment of "Islamic" identity forms (I will only marry a Muslim, I eat only halal food) even as they pursue ostensibly more liberal European or Chinese lifestyles. The students interviewed exhibited a concern with following an authentic brand of Islam, but also a clear desire for breaking away from the strictures of faith. The refugees expressed a more rigid 
perception of Islam, that they would always remain essentially Uyghur and Muslim in their self-reflection and practice, but it is difficult to determine their future in the face of Chinese "re-education" camps.

These different worldviews of the working class and the students point to the salience of social class and gender amidst the claims that such considerations may not be relevant any longer. If anything, emphasis on Islam may galvanize little more than superficial acknowledgment of belief.

What makes the struggle between secular national identity and allegiance a volatile subject is that there is really no clear resolution. Within the realm of Identity, it is difficult to find "coherence" in the midst of individuals engaged in profound "identity" crises. Essentialist identity structures thereby demonstrate their power as simplifiers. The offer subjects easy answers to complicated lifestyles and circumstances. Those who invoke these ideas are often provide political claims to represent or defend an embattled community. An identity such as "Islam" offers individuals an externally validated social place to come to terms with the uncertainty in urban environments where they often face discrimination and economic uncertainty. And they seem to resonate with a human social need for the collective reinforcement of their individual social choices, particularly in circumstances characterized by instability and dispute.

\section{Acknowledgment}

We would like to thank Tubitak, the Scientific and Technological Research Council of Turkey for their support on the Uyghur project

\section{References}

Alemdaroğlu A (2015) Escaping Femininity, Claiming Respectability: Culture, Class and Young Women in Turkey. Women's Studies International Forum 53:53-62.

Bayat A (2010) Life as Politics: How Ordinary People Change the Middle East. Amsterdam: ISIM/Amsterdam University Press.

Bayat A (2013) Arab Spring and Its Surprises. Development and Change 44(3): 587-601. doi: 10.1111/dech.12030.

Baranovich N (2003) From Margins to the Centre: the Uyghur Challenge in Beijing. China Quarterly 175(September): 726-750.

Bovington G (2002) The Not-So-Silent Majority: Uyghur Resistance to Han Rule in Xinjiang. Modern China 28(1): 39-78.

Campante, F R, Chor D (2012) Why was the Arab World poised for Revolution: Schooling, economic opportunities, and the Arab Spring? Journal of Economic Perspectives, 26(2): 167-188.

China Digital Times (2018, November 1) Camps Expand in Xinjiang as Discontent Grows. Retrieved from https://bit.ly/2BDqeT4.

Cole, J (2014) The New Arabs: How the Millennial Generation is changing the Middle East. New York: Simon \& Schuster.

Dekker P, Ester P (2006) Working-Class Authoritarianism: A Re-Examination of the Lipset Thesis. European Journal of Political Research 15: 395 - 415. doi: 
10.1111/j.1475-6765.1987.tb00884.x.

Emet E (2015) Doğu Türkistan Uygur Davası Nedir Olayların Kısa Açılklaması. Retrieved from https://bit.ly/2Shn8K4.

Gest J (2015) Reluctant Pluralists: European Muslims and Essentialist Identities. Ethnic and Racial Studies, Special Issue: Muslims, Migration and Citizenship: Processes of Inclusion and Exclusion 38(11): 1868-1885. doi: 10.1080/01419870.2014.920092.

Gladney D (1992) Ethnic Identity in China: Making of a Muslim Minority Nationality. Wadsworth: Belmont, CA. ISBN10 0155019708 ISBN13 9780155019706.

Hobsbawm E (1999) The Age of Revolution, 1789-1848. California: Textbook Publishers.

Hobsbawm E (2004) The Age of Capital, 1848-1875. New York: Weidenfeld and Nicholson Ltd.

Hobsbawm E (1989) The Age of Empire, 1875-1914. New York: Random House, 1987. First Vintage Books edition.

Julienne M, Rudolf M, Bucknow J (2015)The Terrorist Threat in China. The Diplomat. Retrieved from https://bit.ly/2BDt6PG.

Just A, Sandovici M, Listhaug O (2014) Islam, religiosity, and immigrant political action in Western Europe. Social Science Research 43: 127-144.

Lerner D (1958) The Passing of Traditional Society: Modernizing the Middle East. Glencoe, IL: The Free Press.

Makofsky D (2013) The Artist and the Artisan in Xinjiang (China) Central Asia: the changing Uyghur Muslim culture. European Journal of Applied Social Sciences Research 1(June 1): 29-34.

Makofsky D (2014) The Effectiveness of Affirmative Action Programs in Developing Countries. International Journal for Cross-Disciplinary Subjects in Education (IJCDSE) 5(4).

Millward JA (2009) Introduction: Does the 2009 Urumchi violence mark a turning point? Central Asian Survey 28(4): 347-360.

Moaddel M (1999) Religion and Women: Islamic Modernism vs. Fundamentalism. Journal for the Scientific Study of Religion 37(1): 108-130. 
